\title{
The Research for Management Models of University Teaching Under Credit
}

\author{
Baohua Cui \\ Economic Management Department, \\ Jilin Agricultural University, \\ Changchun, China \\ Email: cbhjlau@yeah.net
}

Key words: credit; teaching management; model

\begin{abstract}
It is a hot topic of social concern to establish teaching model of university management corresponding credit system, this paper analyzes the existing problems and causes for management mode of credit system in Chinese university, put forward to relevant reforms and proposals.
\end{abstract}

\section{Introduction}

Credit is a kind of comprehensive teaching administrative system which is based on elective lessons, in the assistance of teachers' instructor, use credit as a measure to value quality and quantity for students' studies. In China, "Long-term Education Reform and Development Planning outline (2010-2020)" states, we should focus on individual teaching according to different students, pay attention to potential advantages of every student. We carry out teaching administrative systems such as hierarchical teaching, run the class system, credit system, tutorial system, promote credit system reform to become a major component of our education reform. Credit system has a very important role as an advanced teaching management system, which gradually promote and implement the overall healthy development of college students, move forward constantly to administrative work of the college, promote the popular of higher education, drive the progress of society as a whole. However, colleges and universities are lack of awareness for credit in the practical process, lack of relevant experience, which lead to all kinds of bottlenecks problems in practical process of university credit. It has become an important issue to implement the credit system for educational system reforms. How to make a better development for administrative models of credit systems in our Chinese universities, how to make administrative models of credit systems suitable for development situation, how to make full of the key ideology of "people-oriented" in the mode of credit system, which has become a serious challenge in our universities.

\section{The difficulties and cause of credit management in our universities}

A. Defective of teaching planning, insufficient of optional selective courses

Currently most teaching planning of universities are still decidedon the basis of academic year system, emphasize the seriousness and authority of teaching programs, can't reflect a number of new disciplines and results in the teaching, the contents what students learn in school fall behind relatively in the development of society ${ }^{[1]}$. In the teaching planning,some required courses are higher proportion, electives are fewer, the freedom of students' learning are little, we can't combine with characteristics of discipline and can't work out a more scientific and systematic elective series. The conditions of electives, teaching contents from teacher, assessment methods, teaching organization and management are lack of strict requirements.

B. Flexible educational system can not be achieved

In theory, students only attend more than 10 classes everyday and get through test, they can 
take more than 2 years to finish all courses of four years, and then graduate earlier. But due to lack of educational resources, many colleges and universities actually can't open enough electives for students' choice, can't achieve flexible educational system. Furthermore, social employment system corresponding with credit system is imperfect, job market is deficient, even if a small number of students required credits in advance, it can be difficult to graduate early for them.

\section{Students have certain blindness for electives}

The biggest highlight of credit is that students can choose electives independently according to their hobbies. The freedom of choosing electives cross throughout learning phase in university learning. For low-grade students, there is a big blindness at enrollment because their learning objectives are not clear. They will choose courses which get credit easily or have loose teaching management, meet the needs of graduate credit, few students choose a course with certain aim. For senior students, they entry the learning phase of required courses or go to a professional internship, have little opportunity to choose the courses independently, can't choose courses according to their requirements. On the whole, students have certain blindness for electives ${ }^{[2]}$.

\section{The causes of difficulties for promoting credit system in Chinese University}

\section{A. Backward teaching concept}

In management models of long-term planning economics, ideas and concepts of education have been deep-rooted. Students are used to passive learning, lose the consciousness of self-learning gradually, which lead to students' features with poor adaptive ability and more dependent. Credit emphasizes independent learning, students need to develop their own learning plan, but college students don't own capabilities. For some teaching administrators, they focus on the form rather than regulations, can't guide and supervise work well because they don't understand the true meaning of credit system.

\section{B. There is existing problem in school management}

First, teaching management system is not perfect. Every university have introduced their own standard. The definitions in the evaluation criteria and assessment standards are vague so that students feel confused to how to organize their study plans, which make students in a passive position and can't complete their studies in accordance with the requirements of independently learning under credit. Secondly, in academic settings, the majority curriculum of colleges and universities are linked to academic year, students are difficult to learn all required courses for graduation at the same time because of conflict time, or they can't graduate after getting enough credits timely because education administration are lagging, which make credit just a merely form. Finally, in the aspect of administration, the configuration of software facilities aren't perfect in a some colleges and universities, some administrators can’t receive good training, make efficiency low greatly ${ }^{[3]}$.

\section{The system of electives is not perfect}

The core of credit system is elective system, the number and quality of courses will become the key to the success for implementation of credit. Some university exist confused phenomenon for curriculum setting, mainly in the high proportion of professional courses and in the small part of elective courses. So students spend much time to finish professional courses, struggle to cope with elective study.

\section{Improvement of teaching management model under the credit system}

\section{A. Update the ideas and improve the understanding of credit}

To implement credit is the reform for teaching administrative system, also the reform for ideas, concepts and methods of teaching. The credit management is based on electives, allows to choose electives freely, conduct objective management. It is a better system that adapts to the needs of 
social market economy with more perfect teaching management system. In the process of personnel training, we should pay attention to the students' innovative thinking ability, focus on individual education, mobilize students' enthusiasm and explore the potential of students, meanwhile we also mobilize the teachers' initiative in educational reform.

\section{B. Carry out elective system and get through individual teaching}

Setting curriculum is the key for quality of personnel training. Elective system is the basis and prerequisite for the credit system. Sufficient elective course for students to choose is the fundamental and core of credit. Schools offer enough elective courses for their choice. School not only offers professional electives, but strengthen greatly the open of public elective courses. Although the number of existing public elective courses is increasing year by year, it is still insufficient compared to scale of expanding students. Therefore, curriculum design is very important for the implementation of the credit. We not only make full use of freedom for students' enrollment so that students can choose any course according to their interests and social needs, but also ensure the integrity of expertise so that students master the extensive knowledge ${ }^{[4]}$.

\section{Carry out tutorial system, and strengthen guide for electives and study}

Tutorial system is a teaching system which is carried out in university, offer instruction for individual's learning, moral and life from teacher in university. In the aspect of elective, although students' electives are relatively free, the structures of course have the feature of integrity. If we don't understand internal relations, we pursue credits blindly and cater to personal interests unilaterally when choosing the electives, which leads to fragmented knowledge structure and can't form a system. At this time, we need experienced teachers who give guidance for aspirations of career, learning ability, hobbies and family, and give a comprehensive analysis for all information. Meanwhile, teachers also guide students to choose course according to procedures of school, help them to choose electives scientifically and rationally.

\section{Carry out flexible management system}

First, flexible educational system. Basic school system of stipulated professional catalog issued by the Ministry of Education as a reference, it allows students to finish the total credits of school rules in 3 to 8 years, allows outstanding students to get required credits and graduate in advance, allows students with learning difficulties to delay graduation, allows students to suspend their studies according to their own economic, family and business, allows students suspend their study and do business. Secondly, credit point system. It is a measurable standard related to the quantity and quality of students' learning. We accumulate academic records from high to low as point credit, which is the calculation method ${ }^{[5]}$. We will use the cumulative GPA as the basis of graduate qualification, degree assessment, evaluation and application of minor. Thirdly, minor system and second degree system. Minor system is teaching management system which meets the needs of socialistic market economy, widen students' specialty caliber, cultivate comprehensive talents.

\section{E. Test management system combing flexible and strict}

The students' achievement assessment which closely related to credit can ensure quality of credit operations in a degree, test management under credit system reflects fully the principle combining flexibility with strict. Firstly, exemption, listening freely, discontinuous lectures system; secondly, make-up examination system; thirdly, rebuilt and re-examination system; fourth, the implementation of test database system, separation of teaching and testing.

\section{Conclusion}

In short, the credit system is an inevitable development trend in educational administration work, is an important step toward university administration management reform. Each university has its own teaching characteristics, which universities must recognize their own level and stage of continuous development and improvement in practice, continue to reflect and summarize, the only way to promote the improvement of the credit system construction, in order to make teaching level 
continues to increase.

\section{References}

[1] Ministry of Education of People's Republic of China. National long-term education reform and development plan (2010 - 2020) [N]. People's Daily, $2010-7-30$.

[2] Huang Ping. Thoughts on Credit System of Higher Education in China [J]. Market Weekly, 2012(11):12-13.

[3] Wu Lihua, Wu Sensen. The Credit System of Universities must be based on scientific teaching and management, [J], Journal of Jiangxi Science and Technology Normal University, 2008,(8).

[4] Han Hong. On University Credit development, [J]. Journal of Jinan University, 2013, 23(6) : $57-63$.

[5] Zhang Jianzhi, Feng Sun, Liu Yanhong. Suggestions on the process of University Credit improvement, [J]. Modern Enterprise Education, 2013， 8:167. 